\title{
The subjective well-being of students in different parts of a school premises in French middle schools
}

Abstract

The aim of this study was to explore the spatial approach to well-being in French middle schools, drawing on an ecological model of child development to explore how student well-being varies through the day according to the part of the school premises they are in. 2028 (from 11 to 15 years old) students took part in the survey. The results confirm that a spatial approach is interesting because it reveals different levels of subjective well-being according to place. The results also show that the decrease in student well-being between the first and the fourth year is more about learning spaces; other spaces do not result in this decrease. Our study highlights the usefulness of this ecological framework and the importance of complementary qualitative approaches and studies in different cultural contexts for a better understanding of variations in student well-being.

Keywords

places; ecological framework; France; subjective well-being; school; spatial approach

\section{Introduction}

It is essential to explore children's well-being at school in view of the amount of time they spend in this institution (Hui and Sun 2010). A low level of well-being at school is likely to lead to high anxiety scores and depressive symptoms (Huebner and Gilman 2006), whereas high school satisfaction scores impact positively on a student's mental health (Salmena-Aro and Tynkkynen 2010; Shin et al. 2010). Studying student well-being (SWB) at school therefore appears to be essential from a health perspective. Noddings (2003) notes that: "Happiness and education are, properly, intimately connected. Happiness should be an aim of education, and a good education should contribute significantly to personal and collective happiness" (p. 1).

When well-being is investigated in the literature, the question of place is almost entirely absent; SWB is mostly considered at the level of the school or the classroom. Many studies adopt a global approach to investigate well-being 
at school, but the ecological framework of human development (Bronfenbrenner 1989) considers well-being as a consequence of several micro systems interconnected at different levels. We postulate in this study that well-being may vary in the course of a day according to the places in which students find themselves. This paper adopts a faceted spatial approach (where the facets are the different places in the school premises) to provide a better understanding of the dynamics of student subjective well-being (SSWB) at school, and its decrease during middle school (from 11 to 15 years old in France).

\subsection{The ecological model of child development}

Bronfenbronner's (1992) ecological model offers a model for understanding child development and child well-being. It presumes that individual human development evolves within the contexts of interconnected systems (micro-, meso, exo-, macro-, and chronosystems), with the individual at the center (McWhirter et al. 2017). Bronfenbrenner (1979, p. 22) defines a microsystem as "a pattern of activities, roles, and interpersonal relations experienced by the developing person in a given setting with particular physical and material characteristics". Studies generally include the school overall as a microsystem, however, according to Bronfenbrenner's definition, each separate place within a school can be considered a microsystem, which allows us another and deeper understanding of SWB. It would therefore be appropriate to take a spatial approach to investigating the dynamics of SWB according to the different school areas and to detect key spaces involved in increasing or decreasing perceptions of SSWB.

\subsection{Well-being in middle school: a sensitive period}

Worldwide, subjective well-being and satisfaction at school in general tend to decrease with age: primary school students have greater school satisfaction than middle school students (Gonzalez-Carrasco et al. 2016, for a study of Spanish children; Randolph et al. 2010 on Finnish and Dutch children; Okun et al. 1990 or Elmore and Huebner 2010 in an American context; Hui and Sun 2010 for China; Danielsen et al. 2011 for Norway; Lester and Cross 2015 for Australia; and Guimard et al. 2015 and 2017 for France). The decrease in SSWB continues through the years of middle schooling, especially among girls (Uusitalo-Malmivaara 2014). Many studies then conclude with the question: how is 
this downward trend to be explained and can school-related happiness be maintained through the years of early adolescence? (Uusitalo-Malmivaara 2014).

Some recent works have examined the primary/secondary transition in order to explain the decrease in SWB associated with this change in educational environment (Gonzalez-Carrasco et al. 2016). Several factors are mentioned to explain this decrease. In the first stage, authors often point to the structural and social changes accompanying this period of rapid physical, social and emotional development as likely to impact on student feelings of loneliness, isolation and victimization (Lester and Cross 2015). Classmate support and a feeling of safety are seen as protective factors (Lester and Cross 2015).

In a second stage, some studies postulate that the change in educational environment (at the architectural or organizational level, for example) is a possible explanation for the decrease in well-being scores associated with entry into secondary school (Eccles et al. 1993). In the "person-environment fit" theory (Hunt 1975), well-being is seen as affected by an adjustment between individual characteristics and the characteristics of the environment (such as a school), the hypothesis being that the cause of the negative psychological changes linked to adolescence is a mismatch between the needs of the adolescent and the social (and educational) environment that is offered. Our work pursues this line of thought by exploring Level 5 of Eccles and Roeser's (2011) model (which describes seven levels of influence of the environment), and specifically the organizational and functional structures of the school (including its material resources) which may play a role in an adolescent's intellectual, social and emotional development. The facets of well-being here include the places that students frequent, and therefore the school's material resources.

The literature doesn't reveal whether the decrease in well-being at school concern everyplaces or only some areas within school. This research means that the decrease in SWB is more precisely described.

\subsection{Dynamic of well-being according to places}

The literature on well-being at school proceeds as if a school is a single place mainly consisting of classrooms. While the school may function as a single unit, however, its premises are made up of different spaces; not only classrooms but also the entrance hall, the playground, the dining room, the corridors, the physical education (PE) changing rooms, the library, and the school bus stop are all places that students frequent and which contribute to the learning and socialization of the young people who use them (Mazalto and Paltrinieri 2013). According to the ecological approach 
(Bronfenbrenner 1985), each place can be considered a microsystem (with which students interact directly) interconnected with others within the school's macrosystem.

The focus on classrooms is readily understood if one considers the time spent in them, which takes up the majority of a student's daily life at school. It may also appear logical in the light of the importance of the quality of the teacherstudent relationship for the student's subjective well-being (Tian et al. 2016), a relationship manifested almost exclusively in the classroom. Many studies, however, show that the quality of relationships with teachers is more decisive in primary than middle school, whereas relations with peers are more important in lower-secondary school than in primary school (Liu et al. 2015). These results invite one to pay closer attention to all areas of the secondary school premises (including the places in which relationships with peers are important, such as the playground or PE changing rooms, for example) and not just the classroom, the central site of learning. It seems to us essential to examine not only the other places where learning takes place, but also the various sites of socialization in order to understand the different facets of well-being in middle school.

As Florin and Guimard (2017, p.48) highlight, "being happy with school overall does not necessarily imply a positive evaluation of all the experiences a student has in this context". We therefore argue that feeling happy at school or in the classroom does not necessarily imply a high level of subjective well-being in each part of the school premises. The aim of this study is thus to explore SWB in the different spaces of the middle school premises.

\subsection{Subjective well-being}

Subjective well-being can be investigated using several methods (Pavot 2018). Subjective well-being can be investigated using several methods (Pavot 2018). Different indicators of subjective well-being can be used, such as the Personal Wellbeing Index (PWI) (Cummins et al. 2003), or a single item scale regarding overall life satisfaction (OLS, Campbell et al. 1976), such as The Student Life Satisfaction Scale (SLSS, Huebner 1991). These scales give a global vision of SWB pointed out the key role of satisfaction with "my life as a student" in a worldwide study (Casa and González 2017). This invites an emphasis on the many inter-individual differences: feelings of happiness and satisfaction differ strongly from one individual to another (Myers 1992; Ryff 1995; Waterman 1993), and according to cultural contexts (Diener et al. 1995), interlinguistic and intercultural contexts (Casa and González 2017). At an 
individual level, subjective well-being may be treated as a stable data point (Cummins 2010), but also as a state that varies from one day to another and from one environment to another (Reis et al. 2000).

There are several ways of envisaging a student's answer to the question "Do you feel happy at school?": either that the student's appreciation reflects the linear reality of their feeling of well-being about school and that there is therefore little intra-individual variation; or that the answer may be an average appreciation of personal experiences in the different places and points of a student's daily life at school and that there is therefore great intra-individual fluctuation in well-being. In the latter case, it seems to us essential to specify and examine this dynamic of well-being in middle school.

In accordance with this logic, Diener (1994) noted the need to improve the well-established psychology of self-declared well-being with accounts of situational and circumstantial influences. For that reason, we have chosen in this work to examine the level of SSWB in accordance with a hedonic conception concerned with the (positive or negative) quality of the experiences a student has in the various parts of the school premises (the affective component of subjective wellbeing) and also the satisfaction found in being in the school in a general way (the cognitive component). According to Diener (1984; 1994), a positive sense of subjective well-being consists of experiencing many positive effects and few unpleasant effects, and feeling a high general satisfaction with one's life. Applied to SWB at school, this approach consists of evaluating the quality of the affective experiences that students have in this context and the level of satisfaction they experience in being in it.

An interest in subjective well-being also means highlighting the importance of questioning students directly so as to better understand what they experience in each of the places they visit, and ultimately improving the quality of life in school (Elmore and Huebner 2010; Florin and Guimard 2017). It also makes it possible to focus on measuring the momentary emotional states experienced by the individual (the affective component of well-being; Pavot 2008). This dimension, which is mainly concerned with emotions and positive and negative feelings, is that of the instantaneous, the "here and now", an approach particularly suited to the object of our study.

\subsection{The French national context}

Very few studies have been specifically devoted to SWB in schools in France (Lenoir 2012; Guimard et al. 2015). This preoccupation is relatively recent in the French scientific literature (Lenoir 2012; Ferrière et al. 2016). 
While the results of the 2012 Pisa study show that "four out of five students in OECD countries agree or strongly agree that they feel happy at school or that they feel like they belong at school” (OCDE 2013, p. 18), French students score especially poorly on some indicators of well-being, such as stress in relation to school work (Guimard et al. 2015), perceived social support at school (Currie et al. 2008), or the sense of belonging (OECD 2015). Hubert's study (2015) shows that a pupil's overall sense of well-being declines in the course of middle school between the first year and the fourth year (from 11 to 15 years old). The results of the French study by Guimard et al. (2015) are consistent with this; except for aspects of safety and security, middle school students have distinctly more negative feelings than primary school students as regards their sense of well-being in the classroom and being happy to go to school.

Places alongside the traditional classroom become increasingly numerous and diversified from infant school to high school in France (Derouet-Besson 2005). The space of the school is not only a strongly specified space (immediately recognizable) but also a space fragmented into a diversity of places and uses (Sgard and Hoyaux 2006). In French middle school, subjects change each hour or two hours and students have to move; each teacher generally has a specific classroom. Students are thus always moving, and they pass through a variety of places during a school day. Very few studies have investigated these different places in French secondary school. Notable exceptions are the study by Joing and Vors (2015), specifically concerned with bullying and the school climate in the PE changing rooms, and the survey by Hébert and Dugas (2017) on the feeling of security in different parts of middle school premises. Joing and Vors (2015) showed that feelings of safety differ according to the place in which pupils are, and that forms of bullying and misbehavior in a school may be significant and symptomatic of a place: the PE changing rooms for example are a place that favors mockery, the hiding of others' belongings, voyeurism and brawling. Hébert and Dugas (2017) showed that the feeling of safety seems to vary with the places that pupils are in - they feel less safe in unsupervised places such as the playground or the toilets. The aim of the present study is thus to precisely describe student subjective well-being (SSWB) in the different parts of school premises.

\section{Methods}

\subsection{Participants}


A request was sent by email to ten middle schools in the Hauts-de-France region, where we had a contact. ${ }^{1} 2028$ students (between 11 to 16 years old) from these ten schools then participated in the study. Distribution by school year and gender is shown in Table 1.

Table 1. Participant school year and gender

\begin{tabular}{llll}
\hline Participants & Total & Girls & Boys \\
\hline $\mathrm{N}$ & 2028 & 970 & 1041 \\
\hline First year & 612 & 301 & 311 \\
Second year & 583 & 281 & 299 \\
Third year & 390 & 169 & 215 \\
Fourth year & 440 & 219 & 216 \\
Unknown & 3 & - & - \\
\hline
\end{tabular}

\subsection{Survey tool}

This study was conducted by means of a questionnaire designed to evaluate SSWB in the different parts of the school premises. The questionnaire is in three parts. The first collects sociological data such as the name of the school attended, gender, and school year. The second part is concerned with the cognitive component of SWB, and the third part with its affective component.

\subsubsection{Component cognitive of student subjective well-being}

A list of 21 statements was constructed to examine a student's level of general well-being in the school, and also in each of the 19 places identified for the study. ${ }^{2}$ The level of subjective well-being is examined using a "broadhand"

${ }^{1}$ These were teachers with whom we had previously worked (regular reception of trainee teachers, for example). The sample is therefore non-probabilistic.

2 The 19 places asked about are: classroom, resource center/library, supervised work room, sports hall, corridors, stairs, locker area, entrance hall, bicycle shed, Physical Education changing rooms, toilets, administrative offices, Principal Educational Advisor's (PEA) office, playground, dining room, supervisors' office, "gate," school bus stop, swimming pool. 
single-item (Pavot 2018): "I feel good at school" or "I feel good in the classrooms"3 for example. For each item, the student has to position themselves on a five-point Likert scale (from $1=$ strongly disagree, to $5=$ totally agree). The student is asked not to answer if they never or rarely (less than twice a year) visit a place. The cognitive component of student overall subjective well-being at school is also evaluated using a single typical item (Huebner 1994) to assess overall life satisfaction in the middle school: "I am glad to come to school."4 An indicator out of 5 is calculated for each item and each place. The closer the score is to 5, the more the student agrees that they feel good in the place concerned.

\subsubsection{Affective component of students' subjective well-being}

The affective component of the SSWB is evaluated using the French version (validated by Martin-Krumm and his colleagues in 2017) of the scale devised by Diener and his colleagues (2010): the Scale of Positive and Negative Experience (SPANE). This tool asks the respondent to think about what they have been doing in the past four weeks (in the place specified for the present study) and to indicate how much, on a five-point scale of frequency (from $1=$ very rarely or practically never, to $5=$ very often or always), they experienced the feelings listed. The list contains twelve items corresponding to six positive feelings (e.g. "I felt good"5) and six negative feelings (e.g. "I felt sad"6). The student is asked not to reply if they never or only rarely visit a place (less than twice a year).

The scores for the six positive dimensions are added together to give the "SPANE P". The scores for the negative dimensions are also added together ("SPANE N"). The final indicator of affective well-being is obtained by subtracting the SPANE N from the SPANE P (SPANE P - SPANE N). This indicator can thus range from -24 to +24 . A score close to 24 means that the student experiences only positive affects in that place. A negative score means that experiences in that place are regularly associated with negative effects, and thus indicates a low level of affective wellbeing.

Asking about the affective well-being of all students for all 19 places in the study would undoubtedly have introduced a strong fatigue bias among the respondents (the same questions systematically asked for each place). We therefore

\footnotetext{
${ }^{3}$ The statements in French were: "Je me sens bien dans l'établissement"; "Je me sens bien lorsque je suis dans les salles de classe". 4 "Je suis content-e de venir au college."

5 "Je me suis senti(e) bien."

6 "Je me suis senti(e) triste."
} 
chose to construct five versions of the questionnaire (each version has the same questions but for different places). Each questionnaire then examines the student's affective well-being for three or four different places (varying with the version of the questionnaire). The different versions of the questionnaire were distributed randomly to the students. The number of respondents for each version is shown in Table 2. It should be noted that the version of the questionnaire received is independent of a student's sociodemographic characteristics (gender, school year, type of school).

Table 2. Number of respondents for each version of the questionnaire - Pupils completing the SPANE (Diener et al. 2009) for each place

\begin{tabular}{llcc}
\hline Participants & Total & Girls & Boys \\
\hline $\mathrm{N}$ & 2028 & 970 & 1041 \\
\hline $\begin{array}{l}\text { Version 1: classroom, } \\
\text { administration, bicycle } \\
\text { shed }\end{array}$ & 396 & 195 & 198 \\
$\begin{array}{l}\text { Version 2: resource } \\
\text { center, entrance hall, }\end{array}$ & 429 & & \\
$\begin{array}{l}\text { PEA's office, }{ }^{7} \text { school } \\
\text { bus stop }\end{array}$ & & 211 & 214 \\
$\begin{array}{l}\text { Version 3: supervised } \\
\text { work room, playground, } \\
\text { forecourt, dining room }\end{array}$ & 417 & & \\
$\begin{array}{l}\text { Version 4: sports hall, } \\
\text { toilets, stairs }\end{array}$ & 412 & 212 & 203 \\
$\begin{array}{l}\text { Version 5: corridors, PE } \\
\text { changing rooms, } \\
\text { supervisors' office, } \\
\text { locker area }\end{array}$ & 368 & 183 & 223 \\
\end{tabular}

\subsection{Data analysis}

Standard statistical methods were used to calculate the means and standard deviations of the data. Normal Gaussian distribution and the sphericity of the data were verified using the Shapiro-Wilk and Mauchley tests. In the first step, single-sample t-test - were made between each place score and the mean values of each indicator of well-being

7 The "Principal Education Advisor" (PEA, i.e. Conseiller Principal d'éducation, CPE or surveillant général) is in charge of disciplinary matters. Pupils therefore visit the office if they have misbehaved. 
(comparison of means with a standard). The significance level was set at 0.05 for all tests used, to which we applied the Bonferroni correction (given that 19 places $^{8}$ are studied and compared, the significance threshold was set at 0.0026 ).

In the second step, a triple ANOVA (gender x school x school year) was performed for each school location detected as different significatively (step 1) in order to detect any effects of "school," "school year," and "gender." Bonferroni test s was used as a post hoc test, and eta squared values $(\eta 2)$ were calculated to qualify the effect of size. We followed the recommendations of Cohen (1988) to consider the effect small when $\eta 2=0.01$, medium when $\eta 2=0.06$, and large when $\eta 2=0.14$. The free $\mathrm{R}$ software was used for these statistical analyses.

\subsection{Procedures}

The fieldwork was undertaken in March-April 2017 in the ten schools previously contacted in the Hauts-de-France region. One or several contact teachers in each school were trained to organize the completion of the questionnaire. In particular, they had to scrupulously observe written completion instructions. These contained the instructions to be given to the students (introduction of the study, assurance of anonymity, explanations particularly as regards the response scale for first year students) and emphasized the importance of the random distribution of the different versions of the questionnaire. The average time taken to complete the questionnaire was 30 minutes.

In accordance with French law and the European regulation on data protection, a declaration was made and authorization was registered and published under no. 2018-7 of the data-processing register of the University of Lille. This procedure guarantees the anonymity of participants (students and schools) and secure data storage (data encryption and authentication required). In addition, the head teacher is informed of the purpose of the study and of the right of access, rectification and deletion of data concerning his or her school. The researcher's personal details and the CIL declaration number were sent to the heads of the schools.

\section{Findings}

819 places for the cognitive component of well-being and 18 for the affective component, since the swimming pool was not included for the latter. 
This study measures different components of middle school SSWB according to the different places they visit to better understand the decrease in well-being during middle school. Results show that there are different facets of well-being in the middle school depending on the places in which a student may be, and that the decrease in well-being during middle school affects only some places.

\subsection{The cognitive component of subjective well-being}

\subsubsection{Variation in SSWB according to the place}

For all the places taken together, the mean indicator of well-being is 3.94. The indicators of cognitive well-being in the different parts of the middle school are given in Table 3. The results of a comparative analysis show that wellbeing is significantly high in the playground $\left(\mathrm{I}=4.48 ; \mathrm{SD}=0.84 ; \mathrm{p}<.0026^{9}\right)$, in the sports hall $(\mathrm{I}=4.31 ; \mathrm{SD}=0.99 ; \mathrm{p}$ $<.0026)$, in the dining room $(\mathrm{I}=4.30 ; \mathrm{SD}=0.95 ; \mathrm{p}<.0026)$, at the school entrance (the "gate") $(\mathrm{I}=4.07 ; \mathrm{SD}=1.15 ; \mathrm{p}$ $<.0026)$, and in the corridors $(\mathrm{I}=4.02 ; \mathrm{SD}=1.06 ; \mathrm{p}<.0026)$. At threshold $\mathrm{p}<.05$, the indicator of student cognitive well-being is also significantly high in the entrance hall $(\mathrm{I}=4.01 ; \mathrm{SD}=1.11 ; \mathrm{p}<.05)$ and at the school bus stop (I=4.04; $\mathrm{SD}=1.25 ; \mathrm{p}<.05)$

By contrast, the results show a significantly low indicator of cognitive well-being in the following places: the Principal Educational Advisor's (PEA) office $(I=3.14 ; \mathrm{SD}=1.53 ; \mathrm{p}<.0026)$, the toilets $(\mathrm{I}=3.15 ; \mathrm{SD}=1.42 ; \mathrm{p}<.0026)$, the administrative building $(\mathrm{I}=3.54 ; \mathrm{SD}=1.31 ; \mathrm{p}<.0026)$, the supervised work room $(\mathrm{I}=3.54 ; \mathrm{SD}=1.26 ; \mathrm{p}<.0026)$, the classrooms $(\mathrm{I}=3.70 ; \mathrm{SD}=1.09 ; \mathrm{p}<.0026)$, the bicycle shed $(\mathrm{I}=3.75 ; \mathrm{SD}=1.37 ; \mathrm{p}<.0026)$, the locker area $(\mathrm{I}=3.82$; $\mathrm{SD}=1.26 ; \mathrm{p}<.0026)$, and the stairs $(\mathrm{I}=3.87 ; \mathrm{SD}=1.16 ; \mathrm{p}<.0026)$. It should also be noted that at threshold $\mathrm{p}<.05$, the indicator of student cognitive well-being is also significantly low in the supervisors' office $(\mathrm{I}=3.88 ; \mathrm{SD}=1.16 ; \mathrm{p}$ $<.05)$.

\footnotetext{
${ }^{9}$ We apply the Bonferroni correction to the initial threshold of $\mathrm{p}=0.05$ : given that there are 18 places, the corrected value of $\mathrm{p}=0.05 / 18=0.0027$.
} 
Table 3. Indicators of well-being (cognitive component) by places visited; single-sample t-tests showing differences between place scores and mean scores

\begin{tabular}{|c|c|c|c|c|c|c|}
\hline Variable & Mean & SD & SE & $\begin{array}{l}\text { Reference } \\
\text { value }\end{array}$ & Value $\mathrm{t}$ & $\mathrm{p}$ \\
\hline Classrooms & $3.7033 * *$ & 1.0922 & 0.0245 & 3.94 & -9.6214 & $0.000000 * *$ \\
\hline Resource center & 3.9016 & 1.2739 & 0.0304 & 3.94 & -1.2586 & 0.208377 \\
\hline Supervised work room & $3.5465 * *$ & 1.2632 & 0.0284 & 3.94 & -13.8143 & $0.000000 * *$ \\
\hline Sports hall & $4.3192 * *$ & 0.9978 & 0.0224 & 3.94 & 16.8573 & $0.000000^{* *}$ \\
\hline Swimming pool & 3.9095 & 1.4173 & 0.0404 & 3.94 & -0.7529 & 0.451658 \\
\hline Playground & $4.4868 * *$ & 0.8442 & 0.0189 & 3.94 & 28.8222 & $0.000000^{* *}$ \\
\hline Dining room & $4.3084 * *$ & 0.9575 & 0.0240 & 3.94 & 15.2893 & $0.000000 * *$ \\
\hline Toilets & $3.1525 * *$ & 1.4277 & 0.0338 & 3.94 & -23.2889 & $0.000000^{* *}$ \\
\hline PE changing rooms & 3.9851 & 1.1568 & 0.0261 & 3.94 & 1.7225 & 0.085130 \\
\hline Stairs & $3.8784 * *$ & 1.1684 & 0.0272 & 3.94 & -2.2556 & $0.024211 * *$ \\
\hline Corridors & $4.0281 * *$ & 1.0650 & 0.0240 & 3.94 & 3.6593 & $0.000260 * *$ \\
\hline Locker area & $3.8228 * *$ & 1.2600 & 0.0349 & 3.94 & -3.3509 & $0.000829 * *$ \\
\hline Entrance hall & $4.0155^{*}$ & 1.1172 & 0.0258 & 3.94 & 2.9204 & $0.003538^{*}$ \\
\hline Forecourt & $4.0795 * *$ & 1.1584 & 0.0264 & 3.94 & 5.2827 & $0.000000^{* *}$ \\
\hline Bus stop & $4.0483^{*}$ & 1.2541 & 0.0406 & 3.94 & 2.6649 & $0.007832 *$ \\
\hline Bicycle shed & $3.7568 * *$ & 1.3706 & 0.0482 & 3.94 & -3.7941 & $0.000159 * *$ \\
\hline Administration & $3.5422 * *$ & 1.3151 & 0.0347 & 3.94 & -11.4403 & $0.000000 * *$ \\
\hline PEA's office & $3.1462 * *$ & 1.5386 & 0.0418 & 3.94 & -18.9832 & $0.000000^{* *}$ \\
\hline Supervisors' office & $3.8823^{*}$ & 1.1651 & 0.0270 & 3.94 & -2.1297 & $0.033326^{*}$ \\
\hline
\end{tabular}

Table 4. School, gender and school year effects on cognitive well-being in each part of school (triple ANOVA)

$\begin{array}{llccccc}\text { Variable } & \begin{array}{l}\text { School effect } \\ \text { (p value) }\end{array} & \begin{array}{c}\text { School size } \\ \text { effect } \\ \text { (Eta-squared) }\end{array} & \begin{array}{c}\text { Gender effect } \\ \text { (p value) }\end{array} & \begin{array}{c}\text { Size gender } \\ \text { effect } \\ \text { (Eta squared) }\end{array} & \begin{array}{c}\text { Year effect } \\ \text { (p value) }\end{array} & \begin{array}{c}\text { Size year effect } \\ \text { (Eta squared) }\end{array}\end{array}$




\begin{tabular}{|c|c|c|c|c|c|c|}
\hline Classrooms & $2.56 \mathrm{e}-05 * * *$ & 0,02 & $0.00785 * *$ & 0,00 & $6.29 \mathrm{e}-13 * * *$ & 0,03 \\
\hline Resource center & $<2 \mathrm{e}-16 * * *$ & 0,08 & 0.05698 & 0,00 & $4.28 \mathrm{e}-12 * * *$ & 0,03 \\
\hline $\begin{array}{l}\text { Supervised work } \\
\text { room }\end{array}$ & $<2 \mathrm{e}-16 * * *$ & 0,05 & $2.97 \mathrm{e}-06 * * *$ & 0,01 & $9.80 \mathrm{e}-05 * * *$ & 0,01 \\
\hline Sports hall & $3.97 \mathrm{e}-10 * * *$ & 0,02 & $1.21 \mathrm{e}-11 * * *$ & 0,02 & $1.14 \mathrm{e}-06 * * *$ & 0,01 \\
\hline Swimming pool & $1.10 \mathrm{e}-06 * * *$ & 0,02 & $4.49 \mathrm{e}-15 * * *$ & 0,05 & $8.94 \mathrm{e}-15 * * *$ & 0,06 \\
\hline Playground & $0.0473 *$ & 0,01 & 0.6939 & 0,00 & 0.2975 & 0,00 \\
\hline Dining room & $3.34 \mathrm{e}-10 * * *$ & 0,00 & 0.723 & 0,00 & $1.08 \mathrm{e}-06 * * *$ & 0,00 \\
\hline Toilets & $1.44 \mathrm{e}-05 * * *$ & 0,02 & 0.175552 & 0,00 & $0.000885 * * *$ & 0,01 \\
\hline $\begin{array}{l}\mathrm{PE} \text { changing } \\
\text { rooms }\end{array}$ & $4.38 \mathrm{e}-05 * * *$ & 0,01 & 0.339 & 0,00 & 0.187 & 0,00 \\
\hline Stairs & $6.86 \mathrm{e}-06 * * *$ & 0,02 & 0.103388 & 0,00 & 0.138944 & 0,00 \\
\hline Corridors & $0.00835 * *$ & 0,01 & $0.02212 *$ & 0,00 & 0.05495 & 0,00 \\
\hline Locker area & $5.04 \mathrm{e}-11 * * *$ & 0,05 & $0.02880 *$ & 0,00 & $5.74 \mathrm{e}-12 * * *$ & 0,04 \\
\hline Entrance hall & $1.56 \mathrm{e}-06 * * *$ & 0,02 & 0.089674 . & 0,00 & $3.50 \mathrm{e}-09 * * *$ & 0,02 \\
\hline Forecourt & $0.000752 * * *$ & 0,01 & $0.002499 * *$ & 0,00 & $0.003325 * *$ & 0,01 \\
\hline Bus stop & $0.0128 *$ & 0,00 & 0.8738 & 0,00 & 0.7631 & 0,00 \\
\hline Bicycle shed & 0.41327 & 0,01 & 0.11585 & 0,00 & 0.42306 & 0,00 \\
\hline Administration & $2.96 \mathrm{e}-05 * * *$ & 0,03 & $1.39 \mathrm{e}-06 * * *$ & 0,02 & $0.00684 * *$ & 0,01 \\
\hline PEA's office & $5.49 \mathrm{e}-08 * * *$ & 0,03 & 0.10973 & 0,00 & 0.11657 & 0,00 \\
\hline $\begin{array}{l}\text { Supervisors' } \\
\text { office }\end{array}$ & $1.49 \mathrm{e}-13 * * *$ & 0,04 & $1.51 \mathrm{e}-06 * * *$ & 0,01 & $0.0353 *$ & 0,00 \\
\hline School & $<2 \mathrm{e}-16 * * *$ & 0,01 & $5.16 \mathrm{e}-06 * * *$ & 0,00 & $<2 \mathrm{e}-16 * * *$ & 0,01 \\
\hline
\end{tabular}




\subsubsection{Effect of school, school year and gender on student cognitive well-being in each part of the school premises}

Overall, the results reveal that first-year middle school students are happier to come to school and feel better there than fourth-year students, not only within the institution as a whole but in most of the areas that comprise it; however the playground, the PE changing rooms, the stairs, the corridors, the bicycle shed, the school bus stop and the PEA's office register no effect of school year (Table 4). The effect size is small (eta squared $\leq 0.02$ ) as regards the supervised work room, sports hall, dining room, toilets, entrance hall, the forecourt (the "gate"), the administration and the supervisors' office. It therefore seems that it is mainly the learning spaces (classrooms, resource center, and swimming pool) that are most impacted by school year and the associated decrease in SWB.

More specifically, the results show that first year students have a higher indicator of overall well-being at school and school satisfaction compared with other students - more of them agree with the statements that they feel good at school (4.27 vs $4.06, \mathrm{p}<.05)$ and are happy to come to school (3.76 vs $3.29, \mathrm{p}<.05)$.

Fourth-year students have a significantly lower indicator of overall well-being at school and school satisfaction than the rest of the sample: they disagree more strongly with the statements that they feel good at school (3.82 vs 4.06, $\mathrm{p}<.05)$ and like coming to school (2.81 vs 3.29). Moreover, post-hoc tests reveal that they obtain a significantly low indicator of cognitive well-being for the following places: classrooms (3.39 vs $3.69, \mathrm{p}<.05)$, resource center ( 3.52 vs $3.89, \mathrm{p}<.05)$, sports hall (4.08 vs 4.31, $\mathrm{p}<.05)$, locker area (3.43 vs 3.82, $\mathrm{p}<.05)$, entrance hall (3.75 vs 4.01, $\mathrm{p}<.05)$, dining room (4.15 vs 4.30, p<.05), forecourt/“gate” (3.90 vs 4.07, p<.05), and swimming pool (3.25 vs 3.90, p<.05).

Regarding the gender effect, girls agree significantly more than boys (and conversely boys agree significantly less than girls) that they are glad to come to school (3.39 vs 3.20, p<.05). Post-hoc tests reveal that they feel better, compared with boysin the following places: the classroom, the supervised work room, the corridors, the locker area, the forecourt, the administration building and the supervisors' office. However, the effect size is very small (eta squared $\leq 0.02$ ). By contrast, girls state that they feel less good, in comparison with boys (and conversely boys feel significantly better) when they are in the sports hall (4.16 vs $4.45, \mathrm{p}<.05)$ or the swimming pool $(3.57 \mathrm{vs} 4.17, \mathrm{p}<.05)$.

Concerning the school effect, all places are affected, except the bicycle shed. However, the effect size is generally very small (eta squared $\leq 0.02$ ). The places that seem to be most affected by a school effect are institutional places such as 
administration buildings, the PEA's office and the supervisor's office as well as places associated with one or more specific adults (resource center and supervised work room)

\subsection{The affective component of subjective well-being}

\subsubsection{Affective well-being in the different parts of the school premises}

The mean overall indicator of affective well-being is 8.94 for all places taken together, with individual indicators ranging from -24 to +24 (total of 7709 observations ${ }^{10}$ ).

The indicators of affective well-being in the different parts of middle school are shown in Table 5. The results of a comparative analysis show that affective well-being is significantly high in the resource center $(\mathrm{I}=11.31 ; \mathrm{SD}=9.55 ; \mathrm{p}$ $\left.<.0026^{11}\right)$, the sports hall $(\mathrm{I}=11.77 ; \mathrm{SD}=8.70 ; \mathrm{p}<.0026)$, the dining room $(\mathrm{I}=13.76 ; \mathrm{SD}=8.47 ; \mathrm{p}<.0026)$, and the playground $(\mathrm{I}=13.86 ; \mathrm{SD}=8.27 ; \mathrm{p}<.0026)$. It should be noted that at threshold $\mathrm{p}<.05$, the indicator of well-being is also significantly high in the PE changing rooms $(\mathrm{I}=9.95 ; \mathrm{SD}=8.37 ; \mathrm{p}<.05)$.

By contrast, the results show a significantly low indicator of affective well-being in the following places: the PEA's office $(\mathrm{I}=2.66 ; \mathrm{SD}=10.62 ; \mathrm{p}<.0026)$, the toilets $(\mathrm{I}=2.83 ; \mathrm{SD}=9.39 ; \mathrm{p}<.0026)$, the supervisors' office (I=6.51; SD

$=9.56 ; \mathrm{p}<.0026)$, and the administrative building $(\mathrm{I}=6.41 ; \mathrm{SD}=9.48 ; \mathrm{p}<.0026)$. It should be noted that at threshold $\mathrm{p}<.05$, the indicator of student well-being is also significantly low on the stairways $(\mathrm{I}=7.57 ; \mathrm{SD}=8.76 ; \mathrm{p}<.05)$.

Table 5. Indicators of affective well-being by place visited; t-tests showing differences between mean scores

\begin{tabular}{lcccccccc}
\multicolumn{1}{c}{ Variable } & Mean & SD & N & SE & $\begin{array}{c}\text { Reference } \\
\text { value }\end{array}$ & Value t & dl & p \\
& & & & & & & \\
\hline Classrooms & 8.512 & 8.975 & 386 & 0.456 & 8.94 & -0.936 & 385 & 0.349638 \\
Resource center & $11.310^{* *}$ & 9.550 & 360 & 0.503 & 8.94 & 4.708 & 359 & $0.000004 * *$ \\
$\begin{array}{l}\text { Supervised work } \\
\text { room }\end{array}$ & 8.264 & 9.326 & 410 & 0.460 & 8.94 & -1.466 & 409 & 0.143400
\end{tabular}

102028 students answered on 3 or 4 places (depending on version of questionnaire).

${ }^{11}$ We apply the Bonferroni correction to the initial threshold of $\mathrm{p}=0.05$ : given that there are 19 places, the corrected value of $\mathrm{p}=0.05 / 19=0.0026$. 


$\begin{array}{lllllllll}\text { Sports hall } & 11.772^{* *} & 8.707 & 397 & 0.437 & 8.94 & 6.481 & 396 & 0.000000^{* *} \\ \text { Playground } & 13.863 & 8.279 & 394 & 0.417 & 8.94 & 11.802 & 393 & 0.000000^{* *} \\ \text { Dining room } & 13.761^{* *} & 8.479 & 378 & 0.436 & 8.94 & 11.054 & 377 & 0.000000^{* *} \\ \text { Toilets } & 2.831^{* *} & 9.394 & 373 & 0.486 & 8.94 & -12.557 & 372 & 0.000000^{* *} \\ \text { PE changing rooms } & 9.958^{*} & 8.377 & 348 & 0.449 & 8.94 & 2.268 & 347 & 0.023917^{*} \\ \text { Stairs } & 7.570^{*} & 8.764 & 338 & 0.476 & 8.94 & -2.872 & 337 & 0.004326^{*} \\ \text { Corridors } & 8.945 & 7.503 & 350 & 0.401 & 8.94 & 0.013 & 349 & 0.989549 \\ \text { Locker area } & 8.630 & 8.179 & 219 & 0.552 & 8.94 & -0.56 & 218 & 0.575577 \\ \text { Entrance hall } & 8.882 & 8.633 & 358 & 0.456 & 8.94 & -0.126 & 357 & 0.899567 \\ \text { Forecourt } & 9.401 & 9.883 & 379 & 0.507 & 8.94 & 0.909 & 378 & 0.363624 \\ \text { School bus stop } & 8.145 & 9.663 & 176 & 0.728 & 8.94 & -1.09 & 175 & 0.276910 \\ \text { Bicycle shed } & 8.748 & 7.601 & 140 & 0.642 & 8.94 & -0.298 & 139 & 0.766162 \\ \text { Administration } & 6.417^{* *} & 9.484 & 255 & 0.593 & 8.94 & -4.246 & 254 & 0.000030^{* *} \\ \text { PEA's office } & 2.668^{* *} & 10.627 & 220 & 0.716 & 8.94 & -8.752 & 219 & 0.000000^{* *} \\ \text { Supervisors' office } & 6.510^{* *} & 9.567 & 312 & 0.541 & 8.94 & -4.485 & 311 & 0.000010^{* *}\end{array}$

Table 6. School, gender and school year effects on affective well-being in each part of school (triple ANOVA)

Variable School effect School size effectGender effectSize gender effect Year effect Size year effect

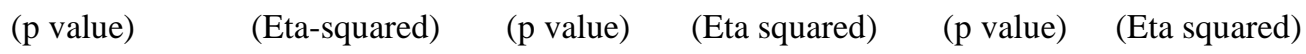

\begin{tabular}{lcccccc}
\hline Classrooms & $0,000000 * *$ & 0,01 & 0,17 & 0,00 & $0,000000^{* *}$ & 0,01 \\
Resource center & $0.000212 * * *$ & 0,06 & $0.020207 *$ & 0,01 & $0.000195 * * *$ & 0,07 \\
Supervised work room $0.0000059 * * *$ & 0,10 & 0.4730 & 0,00 & .0749 & 0,02 \\
Sports hall & $0.02449 *$ & 0,05 & $0.02933 *$ & 0,01 & $0.00475 * *$ & 0,04 \\
Playground & $0.0024 * *$ & 0,07 & 0.5350 & 0,00 & 0.1417 & 0,02 \\
Dining room & 0.31108 & 0,02 & 0.61671 & 0,00 & 0.15951 & 0,02 \\
Toilets & 0.38400 & 0,03 & 0.63945 & 0,00 & $0.00677 * *$ & 0,04 \\
PE changing rooms & 0.478 & 0,03 & 0.176 & 0,00 & 0.374 & 0,01 \\
Stairs & 0.7869 & 0,02 & 0.8699 & 0,00 & $0.0245 *$ & 0,02 \\
Corridors & 0.5091 & 0,02 & 0.7414 & 0,00 & $0.0353 *$ & 0,03
\end{tabular}




$\begin{array}{lcccccc}\text { Locker area } & 0.9075 & 0,03 & 0.9711 & 0,00 & 0.0177 * & 0,05 \\ \text { Entrance hall } & 0.00172 * * & 0,07 & 0.58579 & 0,00 & 0.00430 * * & 0,05 \\ \text { Forecourt } & 0.116 & 0,03 & 0.889 & 0,00 & 0.409 & 0,00 \\ \text { School bus stop } & 0.7121 & 0,06 & 0.5047 & 0,02 & 0.0897 . & \\ \text { Bicycle shed } & 0.2678 & 0,1 & 0.7002 & 0,00 & 0.8103 & 0,00 \\ \text { Administration } & 0.0181 * & 0,08 & 0.0166 * & 0,03 & 0.3814 & 0,02 \\ \text { PEA's office } & 0.3395 & 0,06 & 0.4140 & 0,00 & 0.4559 & 0,02 \\ \text { Supervisors' office } & 0.08317 & 0,03 & 0.30610 & 0,00 & 0.00609 * * & 0,04\end{array}$

\subsubsection{Effect of school, school year and gender on affective well-being in each part of the school premises}

For all places taken together, the results reveal that first-year students have more positive experiences than fourth-year students, for whom the mean indicator of affective well-being is significantly low ( $\mathrm{I}=11.1$ for first year students vs $\mathrm{I}=$ 8.3 for the third year and $\mathrm{I}=8.2$ for the fourth year, $\mathrm{p}<.05$ ). More specifically, post-hoc tests reveal that first-year students have a mean indicator of affective well-being significantly higher than the rest of the sample for the entrance hall (12.16 vs 9.38; $\mathrm{p}<.05)$, the resource center ( 13.39 vs $11.70, \mathrm{p}<.05)$, the stairs $(9.75$ vs $8.42, \mathrm{p}<.05)$, the toilets (6.4 vs 3.37; $p<.05)$, the supervisors' office (10 vs $7.15 ; \mathrm{p}<.05)$, the classrooms (10.97 vs $9.02 ; \mathrm{p}<.05)$, and the sports hall (13.92 vs $12.04 ; \mathrm{p}<.05)$.

By contrast, the fourth year students have more negative experiences compared with other students in the following places: the locker area (6.73 vs 9.21; $\mathrm{p}<.05)$, the corridors (7.17 vs 9.40; $\mathrm{p}<.05)$, the classrooms (5.18 vs 9.02; $\mathrm{p}<.05)$, and the sports hall (9.84 vs 12.04; $\mathrm{p}<.05)$.

The results reveal an effect of gender (with a small effect size; eta squared $\leq 0.03$ ) on the quality of experiences for only two places (Table 6). Girls have a higher score of affective well-being than boys when there are in the resource center (12.76 vs $10.53 ; \mathrm{p}<.05)$ or the administration building $(8.09$ vs $5.91 ; \mathrm{p}<.05)$. 
Concerning the school effect, the following locations show a medium effect size: the resource center, the supervised work room, the sports hall, the playground, the entrance hall, the school bus stop and the administration building (Table 6).

\section{Discussion}

This study is based on an ecological approach to human development (Bronfenbrenner 1989) considering each school place as a microsystem with which students directly interact. The main goal is to provide a better understanding of the dynamics of SSWB at school and its decrease during middle school. By using a large sample, this study provides unique insights into understanding SSWB during middle school.

\subsection{The utility of an ecological approach to school places for analyzing SSWB}

Our results demonstrate the utility of an ecological approach to analyzing SWB. School is not a unique space; it is interesting to divide the school environment into a diversity of places. Indeed, students interacted differently with each of them. A multi-level ecological approach to study and better understand SSWB seems to be promising.

In accordance with early ecological psychology approaches (Barker 1968; Gibson 1950), our results showed the necessity of giving the environment a central place, and revealed that SSWB is situated.

\subsubsection{The "institutional" places, the toilets and the supervised work room: places that perturb well-being}

The results showed that the level of SSWB varies according to the places in which students find themselves. SSWB (cognitive component) is significantly low in the majority of the institutional places, in the supervised work room, and

in the toilets of the school. Student affective well-being is also less good, since the indicator from the SPANE is particularly low for all the "institutional" places and for the toilets. In other words, the students say they have more negative experiences in these places.

There is reason to think that the level of SSWB in some places is conditioned by the activities in which students engage while there. We may therefore propose that the level of SSWB in the institutional parts of the school is linked to the reasons that students are in those places (to receive sanctions, mostly negative; to be interviewed about inappropriate 
behavior, etc., reasons which lead a student to visit the PEA's office or the office of a member of the managerial staff). This nonetheless raises the question of the quality of the teaching (or managerial) staff-student relationship. Few studies have been devoted to this relationship and it would be interesting to examine it more closely with a view to an overall improvement in SWB.

Some recent French studies (AFEV survey in September 2017; Cnesco 2017) have already pointed out the dislike of the toilets by students or the institution. It then seems essential to examine this question specifically, so as to identify what might help to improve the perception of these places and to increase SWB in them. More qualitative and contextualized approaches are necessary.

4.1.2 The places in the school where the students feel good: dining room, sports hall, and playground; places where interpersonal relations are important

The two measures of subjective well-being (cognitive and affective components) concur in showing that the dining room, the sports hall, and the playground are the places where students feel happiest and have the most positive experiences at school, regardless of school year and gender (except for the sports hall, where the boys and the first year students state more strongly than the other students that they feel better). These are places where socializing is likely to be more pronounced (Pourchet and Cerfontaine 2005): the students engage in exchanges there, discuss things that interest them, share good times with their friends, and relax. This result suggests that engaging in social activities that can help to satisfy fundamental psychological needs (here, for relatedness), which impacts positively on the level of well-being in a place. This also relates to the desire for socializing on the part of the students, who pursue two major objectives at school: to follow the lessons (learn) and to socialize (Allen 1986). This idea is strengthened by the fact that the students also state that they also have more positive experiences and feelings in the PE changing rooms regardless of school, gender or school year. This place, although generally described as "problematic" by adults because of the difficulty of supervision (Joing and Vors 2014 2015), is here evaluated positively by the students in terms of affective well-being, no doubt because it offers them a period of conviviality and a privileged occasion for exchanges with same-sex peers. The students also state that they feel particularly good in the corridors of the school or on the forecourt - places through which they reach their classroom and/or wait for the teacher's arrival and the start of the lesson, or wait for the school to open. These times of transition and waiting undoubtedly favor exchanges and discussion among students and so represent periods of conviviality. Finally, the students say they have particularly 
positive experiences (affective well-being) when they are in the resource center, a place where learning is often done autonomously in small peer groups (thus responding to the needs for relatedness and autonomy). These results corroborate the hypothesis of the importance of interpersonal relationships for feeling good in a place. These hypotheses are consistent with a eudaimonic approach to well-being in school, the theoretical framework of which has been developed by some authors in a school context (Baker et al. 2003; Eccles and Roeser 2011; Joing et al. 2018).

\subsection{A decline in the level of subjective well-being through the years of schooling, mainly as regards the learning areas}

The results confirm an internationally observed tendency for the level of well-being to decline through the years of schooling (Gonzalez-Carrasco et al. 2016; Randolph et al. 2010; Okun et al. 1990; Elmore and Huebner 2010; Hui and Sun 2010; Danielson et al. 2011; Lester and Cross 2015; Guimard et al. 2015 and 2017; Uusitalo-Malmivaara 2014; Gonzalez-Carrasco et al. 2016). They also confirm the connection with the chronosystem (Bronfenbrenner 1989): students interact differently with school places with age. They reveal in particular that first-year middle school students are happier to come to school and feel better there than fourth year students, not only in the institution as a whole but in a high proportion of the places it comprises, and especially in the areas devoted to learning (classrooms, resource center, sports hall, swimming pool), which are those, with the locker area, most impacted by school year.

Well-being decreases less in the bicycle shed, school bus stop and playground. All these places are characterized by periods of interpersonal relationships. This supports the conclusions of Liu and colleagues (2015), which showed that relations with peers become more important with age (more important in secondary than primary school). The differences between first and fourth grade students in our work could thus be linked to place, and activities in these places, and not explained by the fact that older students are generally less engaged with school.

This is an important result with which to better understand the decrease in SWB during secondary school.

\subsection{Limitations and perspectives for future studies}


Although this study's findings provide empirical evidence for understanding SWB during French middle school, there are some important limitations to consider when the findings are interpreted. First, although the study uses a large sample of students, the study design is cross-sectional. A better understanding changes in SWB over time would be achieved using a longitudinal dataset.

Second, the analyses revealed a school effect on most of the results. This is the case, for example, for the level of SSWB at the resource center, which seems to be impacted by the school attended: the quality of students' relationships with the teacher in charge of the resource center as well as the way in which the teacher organizes work in this place (for example, does the teacher allow discussion between students or free movement in the place?) probably influences the level of SSWB. Even if the effect size is often small $(\eta 2 \leq 0.01)$ and never large $(\eta 2 \geq 0.14)$, this aspect should be taken into account, as it refers to the particularity of schools. More qualitative research is now needed to understand how the singularities of schools (in terms of functioning or architecture for example) influence the level of SSWB. We agree with Eccles and Roeser (2011, p. 236) when they affirm that "because most school research represents a 'simplification' of young people's actual school experience (Lee, 2000), we believe that the need for rich observational and ethnographic studies of schooling will continue to be important sources of inquiry in the field."

Third, although all possible steps were taken to ensure easy understanding and completion of the questionnaire by the age group concerned (11-15 year olds), the teachers who oversaw its completion sometimes noted a degree of fatigue among some students, induced by the repetitiveness of the questions. Three to four places were asked about in detail in the questionnaires. While it is reasonable to suppose that the student answers for the first two places accurately reflect the reality, it may be that their answers for the fourth place are marked by fatigue bias. This is moreover expressed in part by the number of responses (more non-responses for the last places asked about: bicycle shed, bus stop, dining room, stairs, locker area). The results are based on the students' self-reported evaluations. As with all studies using this methodological approach, judgement and memory may have had an effect. In view of the initial postulate of a dynamic of well-being at school according to place, it would be interesting to pursue the research further with real-time measurements, using the experience sampling method, for example (Csikszentmihalyi 1990). For these reasons more research efforts are needed to better conceptualize and understand SWB during middle school.

Moreover, this study describes a French context in which spaces may be typical or not of schools in other parts of the world. Different cultural contexts must be studied to confirm these early findings. 
Finally, we chose to consider the classroom as a single place for this study, but from the student point of view, there are no doubt as many places as there are different classrooms, and they may well feel comfortable in one room and deeply uneasy in another. There may also have been an effect of time of year (here, March-April) with an impact on the results from the school calendar or the season (end of winter). More qualitative approaches should make it possible to reveal the presence or absence of this effect in the field.

Even with these limitations, we believe the present study contributes toward filling the gap in our knowledge on the reasons that SWB declines as students get older. This study is among the first to explore well-being in the various places of a school premises, based on Bronfenbrenner's ecological model (1992). SSWB is affected by different environmental systems: each area of the school premises is a micro-system in which students are directly connected. This study thus improves our understanding of school well-being and its decrease during middle school, which only be affected in some places. It seems essential to consider all areas of the school premises and not only the school as a whole, or only the classrooms. Feeling happy at school does not automatically mean that a student feels at ease in all parts of it, and vice versa.

The results also tend to suggest that the decline of SWB in middle school could be related to the functionality of spaces. If socialization places are less impacted by school age than learning places, education local policy might make interpersonal relations more central when they design a school, or when they think about internal rules.

An important task for future investigations will be to identify the factors which make a place responsive both to the needs of the users (following the concept of "responsive design") and to institutional constraints and expectations (the need for student supervision, for example), so that students can feel happy, and at the same time the institutional actors can fulfill their functions.

\section{References}

Adie, J. W., Duda, J. L., \& Ntoumanis, N. (2012). Perceived coach-autonomy support, basic need satisfaction and the well-and ill-being of elite youth soccer players: A longitudinal investigation. Psychology of Sport and Exercise, 13(1), 51-59. doi:10.1016/j.psychsport.2011.07.008. 
AFEV (2017). La perception du climat scolaire par les collégiens scolarisés en réseau d'éducation prioritaire, doi: https://drive.google.com/file/d/0B6QNZT6GReI7UXJhVlJ5NEpXZmM/view.

Allen, J. D. (1986). Classroom management: Students' perspectives, goals, and strategies. American Educational Research Journal, 23(3), 437-459.

Baard, P. P., Deci, E. L., \& Ryan, R. M. (2004). Intrinsic need satisfaction: A motivational basis of performance and well-being in two work settings. Journal of Applied Social Psychology, 34(10), 2045-2068, https://doi.org/10.1111/j.1559-1816.2004.tb02690.x

Baker, A. J., Dilly, L. J., Aupperlee, J.L., \& Patil, S.A. (2003). The developmental context of school satisfaction: Schools as psychologically healthy environments. School Psychology Quarterly, 18(2), 206-221

Baker, L. \& Bernstein, H. (2012). The impact of school buildings on student health and performance: A call for research. New York: McGraw-Hill Research Foundation.

Barker, R. G. (1968). Ecological psychology: Concepts and methods for studying the environment of human behavior. Stanford: Stanford University Press.

Barrett, P., Davies, F., Zhang, Y., \& Barrett, L. (2015). The impact of classroom design on students' learning: Final results of a holistic, multi-level analysis. Building and Environment, 89, 118-133. http://dx.doi.org/10.1016/j.buildenv.2015.02.013.

Bronfenbrenner, U. (1979). The ecology of human development. Cambridge: Harvard University Press.

Bronfenbrenner, U. (1989). Ecological systems theory. Annals of Child Development, 6, 187-249.

Bronfenbrenner, U. (1992). Ecological systems theory. In R. Vasta (Ed.), Six theories of child development: Revised formulations and current issues (pp. 187-249). London: Jessica Kingsley Publishers.

Campbell, A., Converse, P. E., \& Rodgers, W. L. (1976). The quality of American life: Perceptions, evaluations, and satisfactions. Nueva York: Russell Sage. 
Casas, F. \& González, M. (2017). School: One world or two worlds? Children's perspectives, Children and Youth Services Review, 80, 157-170.Cohen, J (1988). Statistical power analysis for the behavioral sciences (2nd ed.).

Hillsdale, NJ: Erlbaum.

Conseil National d'Évaluation du Système Scolaire (CNESCO) (2017). Enquête sur la restauration et l'architecture scolaires. Paris: CNESCO.

Courtinat-Camps, A. \& Prêteur, Y. (2010). Expérience scolaire à l'adolescence: quelles différences entre les filles et les garçons? In V. Rouyer, S. Croity-Beltz \& Y. Prêteur (Eds), Genre et socialisation de l'enfance à l'âge adulte (pp. 99-113). Toulouse: Erès.

Csikszentmihalyi, M. (1990). Flow: The psychology of optimal experience. New York: Harper and Row.

Cummins, R. A., Eckersley, R., van Pallant, J., Vugt, J., \& Misajon, R. (2003). Developing a national index of subjective well-being: The Australian unity well-being index. Social Indicators Research, 64, 159-190.

Cummins, R. A. (2010). Subjective wellbeing, homeostatically protected mood and depression: A synthesis. Journal of Happiness Studies, 11, 1-17, https://doi.org/10.1007/s10902-009-9167-0.

Currie, C., Gabhainn, S.N., Godeau, E., Roberts, C., Smith, R., Currie, D., Picket, W., Richter, M., Morgan, A. \& Barnekow, V. (2008). Inequalities in Young people's health. Health behaviour in school-aged children international report from the 2005/2006 survey. Health policy for children and adolescents, $\mathrm{n}^{\circ} 5$.

Danielsen, A., Breivik, K., \& Wold, B. (2011). Do perceived academic competence and school satisfaction mediate the relationship between perceived support provided by teachers and classmates, and academic initiative? Scandinavian Journal of Educational Research, 55, 379-401.

Derouet-Besson, M. (2005). L'apport de l'école à la construction d'une culture architecturale en France, Revue de l’Inspection Générale, 2, 4-19.

Diener, E. (1984). Subjective well-being. Psychological Bulletin, 95, 542-575.

Diener, E. (1994). Assessing subjective well-being: Progress and opportunities. Social Indicators Research, 31(2), $103-157$. 
Diener, E., Diener, C., \& Diener, M. (1995). Factors predicting the subjective well-being of nations. Journal of Personality and Social Psychology, 69, 851-864.

Diener, E., Wirtz, D., Tov, W., Kim-Prieto, C., Choi. D., Oishi, S., \& Biswas-Diener, R. (2010). New well-being measures: Short scales to assess flourishing and positive and negative Feelings. Social Indicators Research, 97, 143156.

Duru-Bellat, M. (2010). Ce que la mixité fait aux élèves. Revue de l'OFCE, 114, 197-212.

Eccles, J., Midgley, C., \& Adler, T. (1984). Grade-related changes in the school environment: Effects on achievement motivation. In J.G. Nicholls (Ed.), The development of achievement motivation (pp.283-331). Greenwich, CT: JAI Press

Eccles, J.S. \& Midgley, C. (1989). Stage/environment fit: Developmentally appropriate classrooms for early adolescents. In R.E. Ames \& C. Ames (Eds.), Research on motivation in education (Vol. 3, pp.139-186). San Diego, CA: Academic Press.

Eccles, J. S., Midgley, C., Wigfield, A., Buchanan, C. M., Reuman, D., Flanagan, C., \& Mac Iver, D. (1993). Development during adolescence: The impact of stage-environment fit on young adolescents' experiences in schools and in families. American Psychologist, 48(2), 90-101.

Eccles, J.S. \& Roeser, R.W. (2011). School and community influences on human development. In M.H. Borstein \& M.E. Lamb, Developmental Science: An Advanced Textbook (pp.571-642). New York: Psychology Press.

Elmore, G.M. \& Huebner, E. S. (2010). Adolescents' satisfaction with school experiences: Relationships with demographics, attachment relationships, and school engagement behavior. Psychology in the Schools, 47(6), 525-537.

Ferrière, S., Bacro, F., Florin, A. \& Guimard, P. (2016). Le bien-être en contexte scolaire: Intérêt d'une approche par triangulation méthodologique. Cahiers Internationaux de Psychologie Sociale, 111, 341-365.

Florin, A. \& Guimard, P. (2017). La qualité de vie à l'école. Paris: Conseil National d'Évaluation du Système Scolaire (CNESCO).

Gibson, J. J. (1950). The perception of the visual world. Boston: Houghton Mifflin 
Gillet, N., Forest, J., Benabou, C., \& Bentein, K. (2015). The effects of organizational factors, psychological need satisfaction and thwarting, and affective commitment on workers' well-being and turnover intentions. Le Travail Humain, 78, 119-140. doi: 10.3917/th.782.0119

Gonzalez-Carrasco, M., Casas, M., Vinas, F. \& Dinisman, T. (2016). Changes with age in subjective well-being through the adolescent years: Differences by gender. Journal of Happiness Studies, 18 (1), 63-88.

Guimard, P., Bacro, F., Ferrière, S., Florin, A., Gaudeville, T., \& Ngo, H.T. (2015). Le bien-être des élèves à l'école et au collège. Validation d'une echelle multidimensionnelle, analyses descriptives et différentielles. Education \& Formations, 88/89, 163-184.

Guimard, P. Bacro, F., Ferrière, S., Florin, A. \& Gaudonville, T. (2017). Evaluation du bien-être perçu des élèves: étude longitudinale à l'école élémentaire et au collège. Recherche complémentaire (BE-Scol2). Rapport pour la Direction de l'évaluation de la prospective et de la performance. Convention 2015 - DEPP - 028.

Hébert T. \& Dugas E. (2017). Quels espaces scolaires pour le bien-être relationnel ? Enquête sur le ressenti des collégiens français. Éducation et Socialisation, Les Cahiers du CERFEE, 43. DOI : 10.4000/edso.1904

Huebner, E. S. (1991). Initial development of the student's life satisfaction scale. School Psychology International, 12(3), 231-240. Huebner, E.S., \& Gilman, R. (2006). Students who like and dislike school. Applied Research in Quality of Life, 1, 139-150

Hui, E. \& Sun, R. (2010). Chinese children's perceived school satisfaction: the role of contextual and intrapersonal factors. Educational Psychology: An International Journal of Experimental Educational Psychology, 30(2), $155-172$.

Hunt, D.E. (1975). Person-environment interaction: A challenge found wanting before it was tried. Review of Educational Research, 45, 209-230

Huyghebart, T., Gillet, N., Fernet, C., Lahiani, F.J., Chevalier, S., \& Fouquereau, E. (2017). Investigating the longitudinal effects of surface acting on managers' functioning through psychological needs. Journal of Occupational Health Psychology, doi: 10.1037/ocp0000080. 
Joing, I. \& Debarbieux, E. (2013). Quand on t'agresse, t'es de quel genre? Etude des réactions des élèves confrontés à une situation potentiellement violente en fonction du sexe, du niveau de classe et du type d'établissement. Revue Recherches et Educations, 9, 43-61.

Joing, I. \& Vors, O. (2014). Le temps des vestiaires d'EPS au collège: climat, victimation et stratégies enseignantes, Congrès de l'ARIS: Geneva.

Joing, I. \& Vors, O. (2015). Victimation et climat scolaire au collège: les vestiaires d'Education Physique et Sportive. Déviance et Société, 39(1), 51-71.

Joing, I., Vors, O., Lléna, C., \& Potdevin, F. (2018). Se sentir bien dans chacun des lieux de l'espace scolaire au college. Le role de l'autonomie, de l'appartenance sociale, de la perception du lieu et du sentiment de sécurité, SpiralE, Revue de recherches en Éducation, 61, 19-40.

Lee, V. E. (2000). Using hierarchical linear modeling to study social contexts: The case of school effects. Educational Psychologist, 35, 125-142.

Lester, L. \& Cross, D. (2015). The relationship between school climate and mental and emotional wellbeing over the transition from primary to secondary school. Psychology of Well-Being: Theory, Research and Practice, 5(9), doi: 10.1186/s13612-015-0037-8.

Lenoir, M. (2012). Le bien-être de l'élève au college: representations des professeurs et des élèves, Université de Lyon 2: thèse de doctorat.

Lentillon, V., \& Trottin, B. (2005). Relations éducatives en éducation physique et sportive et perceptions chez des collégiennes et des collégiens. Education et francophonie, 33(1), 57-72.

Liu, W., Mei, J., Tian, L., \& Huebner, E.S. (2015). Age and gender differences in the relation between school-related social support and subjective well-being in school among students. Social Indicators Research, 125(3), $1065-1083$.

Mazalto, M. \& Paltrinieri, L. (2013). Espaces scolaires et projets éducatifs. Revue internationale d'Education de Sèvres, 64, 31-40. 
McWhirter, J. J., McWhirter, B. T., McWhirter, E. H., \& McWhirter, A. C. (2017). At risk youth: A comprehensive response for counselors, teachers, psychologist, and human service professionals. Boston: Cengage Learning.

Myers, D. G. (1992). The pursuit of happiness: Who is happy - and why. New York: William Morrow.

Nguyen, T.P. (2016). La qualité de vie et le bien-être à l'école en France: quelle place dans les textes institutionnels? Rapport commandité par le Conseil National d'Évaluation du Système Scolaire (CNESCO).

Noddings, N. (2003). Happiness and education. Cambridge: Cambridge University Press.

OCDE (2013). France. Pisa 2012: faits marquants. https://www.oecd.org/france/PISA-2012-resultsfrance.pdf

OCDE (2015). Relations enseignants-élèves: quelle incidence sur le bien-être des élèves à l'école ? Pisa à la loupe, $\mathrm{n}^{\circ} 50$, Edition de l'OCDE.

Okun, M. A., Braver, M. W., \& Weir, R. M. (1990). Grade level differences in school satisfaction. Social Indicators Research, 22, 419-427.

Pavot, W. (2018). The cornerstone of research on subjective well-being: Valid assessment methodology. In E. Diener, S. Oishi, \& I. Tay (Eds.), Handbook of well-being. Salt Lake City: DEF Publishers.

Pourchet G. \& Cerfontaine J. Y. (2005). Des espaces d'enseignement aux lieux de vie : leçons d'une enquête. Revue de l'Inspection Générale, 2, 47-55.

Randolph, J., Kangas, M.M., \& Ruokamo, H. (2010). Predictors of Dutch and Finnish children's satisfaction with schooling. Journal of Happiness Studies, 11, 193-204.

Reis, H. T. (1994). Domains of experience: Investigating relationship processes from three perspectives. In R. Erber \& R. Gilmour (Eds.), Theoretical frameworks for personal relationships (pp. 87-110). Hillsdale, NJ: Lawrence Erlbaum.

Reis, H.T., Sheldon, K., Gable, S., \& Ryan, R.M. (2000). Daily well-being: The role of autonomy, competence, and relatedness. Personality and Social Psychology Bulletin, 26(4), 419-435.

Ryan, R. M. (1995). Psychological needs and the facilitation of integrative processes. Journal of Personality, 63, $397-427$. 
Ryff, C. D. (1995). Psychological well-being in adult life. Current Directions in Psychological Science, 4, 99-104.

Salmena-Aro, K., \& Tynkkynen, L. (2010). Trajectories of life satisfaction across transition to post-compulsory education: Do adolescents follow different pathways? Journal of Youth and Adolescence, 39, 870-881.

Sgard, A. \& Hoyaux, A.F. (2006). L'élève et son lycée: de l'espace scolaire aux constructions des territoires lycéens, L'information géographique, 70 (3), 87-108.

Sheldon, K., \& Kasser, T. (1995). Coherence and congruence: Two aspects of personality integration. Journal of Personality and Social Psychology, 68, 531-543.

Sheldon, K. M., Ryan, R. M., Rawsthrne, L., \& Ilardi, B. (1997). "True” self and "trait” self: Cross-role variation in the Big Five traits and its relations with authenticity and well-being. Journal of Personality and Social Psychology, 73, 1380-1393.

Sheldon, K. M., Ryan, R. M., \& Reis, H. T. (1996). What makes for a good day? Competence and autonomy in the day and in the person. Personality and Social Psychology Bulletin, 22, 1270-1279.

Shin, R., Morgan, M., Buhin, L., Truitt, T., \& Vera, E. (2010). Expanding the discourse on urban youth of color. Cultural Diversity and Ethnic Minority Psychology, 16, 421-426.

Tian, L., Tian, Q \& Huebner, E.S. (2015). School-related social support and adolescents' school-related subjective well-being: The mediating role of basic psychological needs satisfaction at school grounded in basic psychological needs theory. Social Indicators Research, 11(4), 227-268, https://doi.org/10.1007/s11205-015-1021-7.

Tian, L., Tian, Q., \& Huebner, E.S. (2016). School-related social support and adolescents' school-related subjective well-being: The mediating role of basic psychological needs satisfaction at school. Social Indicators Research, 128(1), $105-129$.

Uusitalo-Malmivaara, L. (2014). Happiness decreases during early adolescence - a study on 12- and 15-year-old Finnish students. Psychology, 5, 541-555, doi:10.4236/psych.2014.56064.

Véronneau, M.H., Richard, F., Koestner, J., \& Abela, R.Z. (2005). Intrinsic need satisfaction and well-being in children and adolescents: An application of the self-determination theory. Journal of Social and Clinical Psychology, 24 (2), 280-292. 
Vigneron, C. (2006). Les inégalités de réussite en EPS: déterminisme biologique ou fabrication scolaire, Revue Française de Pédagogie, 154, 111-124.

Waterman, A. S. (1993). Two conceptions of happiness: Contrasts of personal expressiveness (eudaimonia) and hedonic enjoyment. Journal of Personality and Social Psychology, 64, 678-691.

Whitney, S.D, Renner, L.M., \& Herrenkohl, T.I. (2010). Gender differences in risk/protection profiles for low academic performance. Journal of Community Psychology, 38, 435-455. 